\title{
Klasifikasi Data Antroprometri Individu Menggunakan Algoritma Nä̈ve Bayes Classifier
}

\author{
Johnson Sihombing \\ Sistem Informasi, STMIK Ganesha Bandung, john97.sihombing@gmail.com
}

\section{Keywords:}

Decision Support System, Text classification, Nä̈ve Bayes Classifier, Python

\begin{abstract}
With the development of advances in computer technology today, most companies and organizations need a decision support system based on information systems, where the information is generally stored in the form of documents / text that is not structured. In this regard, a system for text management that is integrated with the decision support system is needed. One of them is the use of text data classification for anthropometric case studies of several samples. Anthropometry is a measurement of a person's body dimensions. The object of research is gender, first name, and height of a person. The research aims to determine the ratio of the number and height probability level of the number of men and women based on the input into an application using the Naïve Bayes Classifier method. The implementation design uses the Python programming language. The results showed that the height classification data frequency of women was more than the height classification data for men. And the number of height probability of a woman's body is greater than the number of height probability of a man's body.
\end{abstract}

\section{Kata Kunci}

Sistem Pendukung Keputusan,

Klasifikasi Teks,

Nä̈ve Bayes Classifier,

Python

\begin{abstract}
ABSTRAK
Dengan berkembangnya kemajuan teknologi komputer saat ini, sebagian besar perusahaan maupun oraganisasi membutuhkan suatu sistem pendukung keputusan yang berbasis sistem informasi, dimana informasi tersebut pada umumnya tersimpan dalam bentuk dokumen/teks yang tidak terstruktur. Sehubungan hal tersebut, dibutuhkan suatu sistem untuk pengelolaan teks yang terintegrasi dengan sistem pendukung keputusan. Salah satunya adalah penggunaan klasifikasi data berbentuk teks untuk studi kasus antropometri dari beberapa sampel. Antropometri adalah pengukuran dimensi tubuh seseorang. Yang menjadi objek peneletian adalah jenis kelamin, nama awal, dan tinggi seseorang. Penelitian ini bertujuan untuk menentukan perbandingan jumlah serta tingkat probalitias tinggi tubuh jumlah pria dan wanita berdasarkan inputan kedalam sutu aplikasi dengan metode Naïve Bayes Classifier. Perancangan implementasi menggunakan bahasa pemrograman Python. Hasil penelitian menunjukkan bahwa frekuensi kemunculan data klasifikasi tinggi tubuh wanita lebih banyak daripada data klasifikasi tinggi tubuh pria. Serta jumlah probabilitas tinggi tubuh wanita lebih besar dari jumlah probabilitas tinggi tubuh pria
\end{abstract}

\author{
Korespondensi Penulis: \\ Johnson Sihombing, \\ STMIK Ganesha Bandung, \\ J1. Raya Militer KM 2 Kp. Cilamega Desa Depok Kec Darangdan, Purwakarta. \\ Telepon: +6282111165381 \\ Email: john97.sihombing@gmaill.com
}

\section{PENDAHULUAN}

\subsection{Latar Belakang}

Teknologi informasi merupakan salah satu bidang yang saat ini berkembang dengan pesat di segala bidang kehidupan. Data/informasi yang melimpah akan dihasilkan oleh teknologi informasi, mulai dari sektor industri, 
ekonomi, serta sektor aplikasi lainnya. Penerapan teknologi informasi dalam kehidupan rumah tangga juga dapat menghasilkan data yang berlimpah mengenai antropometri (ukuran tubuh seseorang).

Pada jaman serba digital dewasa ini, masih terdapat beberapa bidang yang masih menggunakan cara-cara manual untuk mendapatkan data atau informasi, salah satunya adalah bidang antropometri (ukuran tubuh). Dan cara untuk mengukur antropometri seseorang adalah dengan kursi antropometri.

Antropometri merupakan suatu ilmu yang cenderung meneliti ke arah yang berkaitan dalam desain ruang kerja, fasilitas kerja, serta desain produk-produk yang sesuai dengan ukuran tubuh manusia. Tujuan dilakukannya hal tersebut adalah terciptanya suatu kondisi yang nyaman, aman, dan sehat bagi manusia serta menciptakan kondisi kerja yang efisien dengan hasil efektif untuk mencapai keadaan yang ergonomis.

Contoh dampak negatif apabila kita mendesain ruang kerja (interaksi antara operator dengan kursi, meja dan seperangkat komputer) tidak menggunakan antropometri manusia adalah desain workstation tersebut apabila tidak ergonomis dapat menyebabkan penyakit Occupational Ceruicobbrachial Syndrome (OCS), dan kelelahan mata akibat dari lamanya menatap layar monitor atau akibat dari posisi monitor yang tidak sesuai dengan user [1]. Dengan tersedianya data antropometri tubuh manusia Indonesia, maka dapat dideskripsikan ukuran yang presisi dan akurat sesuai dengan ukuran dimensi tubuh manusia Indonesia.

Di Indonesia sendiri, antropometri utamanya digunakan untuk meneliti status gizi pada anak. Hal ini dijelaskan pada Keputusan Menteri Kesehatan No 1995/MENKES/S/2010. Di mana dalam keputusan tersebut pengukuran antropometri mengikuti standar yang telah ditetapkan oleh WHO pada tahun 2005. Pada keputusan tersebut juga dijelaskan mengenai bagaimana tolak ukur yang digunakan dalam mengukur status gizi anak. Beberapa variable yang dicari dalam hal tersebut adalah: umur, panjang badan, tinggi badan, serta berat badan.

Pengukuran antropometri banyak digunakan dalam berbagai kegiatan, diantaranya dalam perekrutan calon pegawai negeri sipil, perekrutan tentara dan sebagai alat bantu dalam praktikum ergonomi [2].

Berdasarkan pendapat-pendapat dan keputusan tersebut di atas, penulis tertarik dan berminat untuk melakukan penelitian terhadap klasifikasi data antropometri tubuh manusia dengan menggunakan algoritma Nä̈ve Bayes. Adapun proses implementasi dilakukan dengan bahasa pemrograman Python.

\subsection{Tujuan Penelitian}

Adapun tujuan yang dilaksanakan penulis pada penelitian ini adalah sebagai berikut:

1. Menghasilkan informasi untuk mendukung proses pengambilan keputusan dalam menentukan jumlah jenis kelamin dan tinggi seseorang.

2. Membuat aplikasi untuk menghitung probabilitas dan frekuensi terhadap komponen-komponen yang terkait dengan pengambilan keputusan.

\section{METODE PENELITIAN}

2.1 Antropometri

\section{A. Pengertian Antropometri}

Berdasarkan pendapat Aritonang Irianton (2013): "antropometri adalah suatu cara penilaian dari pengaruh faktor genetik dan faktor lingkungan terhadap status energi dan protein seseorang". Antropometri memiliki kelebihankelebihan: disamping prosedurnya yang cukup sederhana, juga tingkat keamanan yang tinggi, dan dapat dilakukan dalam jumlah sampel yang besar dan pada umumnya tidak membutuhkan tenaga ahli untuk menangani masalah tersebut [3].

Masih menurut pendapat Aritonang Irianton (2013): jenis pengukuran antropometri yang dilakukan terhadap seseornag adalah berat badan (BB), tinggi badan (TB), lingkar lengan atas (LILA), lingkar kepala (LK), tebal lemak dibawah kulit (TL), serta tinggi lutut [3].

Beberapa aspek yang menjadikan alat tersebut menjadi favorit para konsumen adalah: tidak terlalu mahal, fleksibilitas tinggi, berdaya tahan lama, serta mudah dipesan dan dibuat. Sedangkan kebalikannya adalah pendeteksian status gizi seseorang dapat berlangsung dalam waktu yang relatif lama. Tingkat akurasi dan keabsahan dari pengukuran antropometri akan berkurang jika terjadi kesalahan dalam pengukuran antropometri seseorang [4].

\section{B. Ukuran Antropometri}

Berikut ini adalah jenis-jenis ukuran yang dilakukan untuk antropometri:

\section{a. $\quad$ Berat Badan (BB)}

Berat badan menggambarkan tentang massa tubuh. Dalam keadaan normal, BB berkembang mengikuti perkembangan umur (balita). Sedangkan saat dalam keadaan tidak normal, BB berkembang lebih cepat atau lambat. Berdasarkan sifat tersebut, maka indikator BB/U hanya dapat menggambarkan status gizi saat ini. Prosedur penimbangan BB yaitu (1) dilakukan sebaiknya pagi hari setelah buang air atau keadaan perut kosong supaya hasil akurat, (2) meletakkan timbangan di tempat yang datar, (3) sebelum dilakukan penimbangan sebaiknya timbangan dikalibrasi terlebuh dahulu, (4) klien diminta melepas alas kaki, aksesoris yang digunakan dan menggunakan pakaian seminimal mungkin, (5) klien naik ke timbangaan dengan posisi menghadap kedepan, pandangan lurus, tangan disamping kanan kiri dan posisi rileks serta tidak banyak gerakan, (6) catat hasil pengukuran [3].

b. Tinggi Badan (TB). 
Tinggi badan merupakan gambaran pertumbuhan. Dalam keadaan normal, TB tumbuh bersama dengan pertambahan umur. Pengaruh kekurangan gizi terhadap TB akan tampak pada kekurangan yang sangat lama. Berdasarkan hal tersebut indeks TB/U dapat menggambarkan keadaan masa lalu (Aritonang, 2013). Prosedur pengukuran TB yaitu (1) memasang mikrotoa pada dinding yang rata dan tegak lurus pada lantai, (2) mikrotoa digeser keatas hingga melebihi tinggi anak yang akan diukur, (3) klien berdiri tegak lurus rapat ke dinding, (5) posisi kepala, bahu belakang, pantat dan tumit rapat ke dinding, pandangan lurus ke depan, (6) membaca angka pada mikrotoa dengan pandangan mata sejajar dengan angka yang ditunjuk pada garis mikrotoa [3].

\subsection{Naïve Bayes Classifier}

\section{A. Pengertian Metode Nä̈ve Bayes Classifier}

Nä̈ve Bayes Classifier merupakan sebuah metoda klasifikasi yang berakar pada pengklasifikasian dengan menggunakan metode probabilitas dan statistik yang dikemukakan oleh ilmuwan Inggris Thomas Bayes, yaitu memprediksi peluang di masa depan berdasarkan pengalaman di masa sebelumnya sehingga dikenal sebagai Teorema Bayes. Ciri utama dari Nä̈ve Bayes Classifier ini adalah asumsi yg sangat kuat akan independensi dari masing-masing kondisi/ kejadian.

Menurut Olson Delen (2008) menjelaskan Naïve Bayes untuk setiap kelas keputusan, menghitung probabilitas dengan syarat bahwa kelas keputusan adalah benar, mengingat vektor informasi obyek. Algoritma ini mengasumsikan bahwa atribut obyek adalah independen. Sedangkan jumlah frekuensi yang terdapat pada tabel keputusan merupakan faktor penentu dari probabilitas terhadap perkiraan akhir [5].

Metode Nä̈ve Bayes Classifier bekerja sangat baik dibanding dengan model classifier lainnya. Hal ini dibuktikan oleh Xhemali, Hinde Stone dalam jurnalnya "Naïve Bayes vs. Decision Trees vs. Neural Networks in the Classification of Training Web Pages" mengatakan bahwa "Nä̈ve Bayes Classifier memiliki tingkat akurasi yg lebih baik dibanding model classifier lainnya". Disisi lain, dengan jumlah data pelatihan (training data) yg tidak terlalu besar, maka cukup mudah untuk menentukan perkiraan parameter yang dibutuhkan dalam klasifikasi datanya. Karena yang diasumsikan sebagai variabel independent, maka hanya varians dari suatu variabel dalam sebuah kelas yg dibutuhkan unt menentukan klasifikasi, bukan keseluruhan dari matriks kovarians. Adapun kegunaan dari metode Naïve Bayes Classifier adalah:

a. Mengklasifikasikan dokumen teks seperti teks berita ataupun teks akademis.

b. Sebagai metode machine learning yang menggunakan probabilitas.

c. Untuk membuat diagnosis medis secara otomatis.

d. Mendeteksi atau menyaring spam.

Metode Nä̈ve Bayes Classifier memiliki kelebihan-kelebihan, antara lain [6]:

a. Bisa dipakai untuk data kuantitatif maupun kualitatif.

b. Tidak memerlukan jumlah data yang banyak.

c. Tidak perlu melakukan data training yang banyak.

d. Jika ada nilai yang hilang, maka bisa diabaikan dalam perhitungan.

e. Proses perhitungan yang cepat dan efisien.

f. Mudah dipahami.

g. Mudah dibuat.

h. Pengklasifikasian dokumen bisa dipersonalisasi, disesuaikan dengan kebutuhan setiap orang.

i. Coding yang cukup sederhana jika diimplementasikan kedalaam bahasa pemrograman.

j. $\quad$ Bisa digunakan untuk klasifikasi masalah biner ataupun multiclass.

Metode Nä̈ve Bayes Classifier juga memiliki kekurangaan-kekurangan, yaitu:

a. Apabila probabilitas kondisionalnya bernilai nol, maka probabilitas prediksi juga akan bernilai nol.

b. Asumsi bahwa masing-masing variabel independen yang akan berdampak terhadap berkurangnya akurasi, karena biasanya ada korelasi antara variabel yang satu dengan variabel yang lain.

c. Keakuratan tidak bisa hanya diukur dengan menggunakan satu probabilitas saja, tapi butuh bukti-bukti lain untuk membuktikannya.

d. Untuk membuat keputusan, diperlukan pengetahuan awal atau pengetahuan mengenai masa sebelumnya. Keberhasilan sangat bergantung pada pengetahuan awal tersebut.

\section{B. Teorema Nä̈ve Bayes Classifier}

Menurut Bustami (2013): pada teorema Bayes, bila terdapat dua kejadian yang terpisah (misalkan X dan H), maka Teorema Bayes dirumuskan sebagai berikut [7] :

$$
\mathrm{P}(\mathrm{H} \mid \mathrm{X})=\frac{\mathrm{P}(\mathrm{X} \mid \mathrm{H})}{\mathrm{P}(\mathrm{X})} \cdot \mathrm{P}(\mathrm{H})
$$

Keterangan:

$\mathrm{X} \quad=$ Class data yang dimasukkan; 
$\mathrm{H}=$ Data hipotesis;

$\mathrm{P}(\mathrm{H} \mid \mathrm{X})=$ Probabilitas hipotesis $\mathrm{H}$ yang mengacu pada kondisi $\mathrm{X}$;

$\mathrm{P}(\mathrm{H}) \quad=$ Probabilitas hipotesis $\mathrm{H}$;

$\mathrm{P}(\mathrm{X} \mid \mathrm{H})=$ Probabilitas $\mathrm{X}$ berdasarkan kondisi pada hipotesis $\mathrm{H}$.

$\mathrm{P}(\mathrm{X}) \quad=$ Probabilitas $\mathrm{X}$ berikut:

Teorema Bayes sering pula dikembangkan mengingat berlakunya hukum probabilitas total, menjadi seperti

$$
\mathrm{P}(\mathrm{H} \mid \mathrm{X})=\frac{\mathrm{P}(\mathrm{X} \mid \mathrm{H})}{\sum_{i=1}^{n} P(H i \mid X)} \cdot \mathrm{P}(\mathrm{H})
$$

Keterangan:

$\mathrm{i}=1,2,3, \ldots, \mathrm{n}$ adalah jumlah data hipotesis.

dimana H1 U H2 U H3 ... U Hn = S.

$\mathrm{S}=$ Probabilitas total $\mathrm{H}$ berikut [7] :

Untuk menentukan jenis kelas yang cocok dalam pengklasifikasian, maka rumus diatas disesuaikan sebagai

$$
P(C \mid F 1, \ldots, F n)=\frac{P(F 1, \ldots, F n \mid C)}{P(F 1, \ldots, F n)} \cdot P(H)
$$

Keterangan:

$\mathrm{C} \quad=$ representasi dari kelas.

F1 ...Fn = karakteristik petunjuk yang dibutuhkan dalam proses klasifikasi data

Formula diatas tersebut mendeskripsikan tentang peluang munculnya kelas $\mathbf{C}$ (sebelum masuknya sampel, disebut prior), dikali dengan peluang kemunculan karakteristik-karakteristik sampel pada kelas C (disebut juga likelihood), kemudian dibagi dengan peluang kemunculan karakteristik-karakteristik sampel secara global (disebut juga evidence). Karena itu, rumus di atas dapat pula ditulis secara sederhana sebagai berikut :

$$
\text { Posterior }=\frac{\text { Prior } \times \text { likehood }}{\text { Evidence }}
$$

Dengan asumsi bahwa masing-masing petunjuk (F1, F2, ..., Fn) saling bebas (independen) satu sama lain. Dengan asumsi tersebut, maka berlaku suatu kesamaan sebagai berikut :

$$
P\left(F_{i} \mid F_{j}\right)=\frac{P\left(F_{i} \cap F_{j}\right)}{P\left(F_{j}\right)}=\frac{P\left(F_{1} \cdot F_{j}\right)}{P\left(F_{j}\right)}=P\left(F_{i}\right)
$$

Untuk $\mathrm{i} \neq \mathrm{j}$, sehingga $\mathrm{P}\left(\mathrm{F}_{\mathrm{i}} \mid \mathrm{C}, \mathrm{F}_{\mathrm{j}}\right)=\mathrm{P}\left(\mathrm{F}_{\mathrm{i}} \mid \mathrm{C}\right)$ atau dapat ditulis dalam notasi :

$$
\mathrm{P}\left(\mathrm{c} \mid \mathrm{F}_{1}, \mathrm{~F}_{2}, \mathrm{~F}_{3}, \ldots, \mathrm{Fn}\right)=\mathrm{P}(\mathrm{C}) \prod_{\mathrm{i}=1}^{\mathrm{n}} \mathrm{P}\left(\mathrm{F}_{1} \mid \mathrm{C}\right)
$$

Untuk klasifikasi dengan data kontinyu digunakan rumus Densitas Gauss :

$$
\mathrm{P}\left(\mathrm{X}_{\mathrm{i}}=\mathrm{x}_{\mathrm{i}} \mid \mathrm{Y}=\mathrm{y}_{\mathrm{i}}\right)=\frac{1 e^{\frac{\left(\mathrm{x}_{\mathrm{i}}-\mu_{\mathrm{ij}}\right)^{2}}{2^{2}{ }_{\mathrm{aij}}}}}{\sqrt{2 \pi \sigma \mathrm{ij}}}
$$

Keterangan:

$\mathrm{P}=$ Peluang $; \mathrm{X}_{\mathrm{i}}=$ Atribut ke-i $; \mathrm{x}_{\mathrm{i}}=$ Nilai Atribut ke-i $; \mathrm{Y}=$ Kelas yang dicari $; \mathrm{y}_{\mathrm{i}}=$ Sub-kelas yang dicari $; \mu=$ : mean, yang menyatakan rata-rata dari seluruh atribut ; $\sigma=$ Deviasi Standar, yang menyatakan varian dari seluruh atribut 
Menurut Saleh (2015), diagram alir dari metode Naive Bayes dapat dibuat seperti pada gambar dibawah ini [8] :

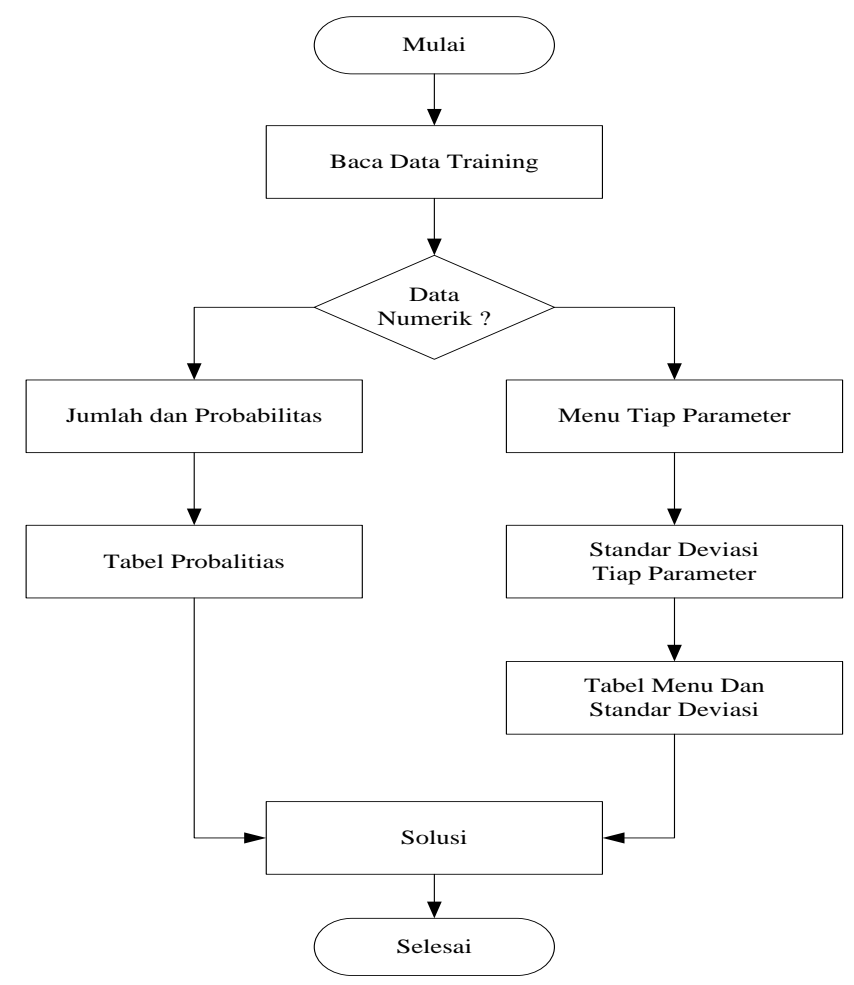

Gambar 1. Diagram Alir Nä̈ve Bayes

\subsection{Laplace Correction}

Manning (2009) berpendapat bahwa Laplace Correction (Laplacian Estimator) adalah suatu cara untuk menangani nilai probabilitas 0 (nol). Dengan melaklukan perhitungan datanya yang ditambah 1 (satu), maka dapat menghindari nilai probabilitas 0 (nol) pada proses klasifikasi. Laplace Correction ini dapat dinyatakan dalam persamaan seperti pada persamaan berikut ini [9] :

$$
\rho i \frac{m_{i}+1}{n+k}
$$

dimana $\mathbf{\rho} \mathbf{i}$ adalah probabilitas dari atribut $\mathrm{m}_{\mathrm{i}}, \mathbf{m}_{\mathbf{i}}$ adalah jumlah sampel dalam kelas dari atribut $\mathrm{m}_{\mathrm{i}}, \mathbf{k}$ adalah jumlah kelas dari atribut $\mathrm{m}_{\mathrm{i}}$ dan $\mathbf{n}$ adalah jumlah sampel.

Contoh: diasumsikan ada class Pembelian BBM = sedang di suatu training set, memiliki 8 sampel, ada 0 sampel dengan Pengeluaran/Bulan $=$ sedikit, 4 sampel dengan Pengeluaran/Bulan $=$ sedang, dan 4 sampel dengan Pengeluaran/Bulan = banyak .

Probabilitas dari kejadian ini tanpa Laplacian Correction adalah:

$\mathbf{P}($ Perngeluaran $/$ Bulan $=$ sedikit $\mid$ Pembelian BBM $=$ sedang $)=0$,

$\mathbf{P}($ Perngeluaran/Bulan $=$ sedang $\mid$ Pembelian $\mathrm{BBM}=$ sedang $)=0.500($ dari $4 / 8)$, dan

$\mathbf{P}($ Perngeluaran/Bulan = banyak $\mid$ Pembelian BBM = sedang $)=0.500($ dari $4 / 8)$.

Dengan menggunakan Laplacian Correction dari tiga kasus diatas, diasumsikan ada satu sampel lagi untuk masing-masing nilai Pembelian BBM = sedikit. Dengan cara ini, didapatkan probabilitas sebagai berikut:

$\mathbf{P}($ Perngeluaran $/$ Bulan $=$ sedikit $\mid$ Pembelian $\mathrm{BBM}=$ sedang $)=0.090($ dari $1 / 11)$

$\mathbf{P}($ Perngeluaran/Bulan $=$ sedang $\mid$ Pembelian $\mathrm{BBM}=$ sedang $)=0.454($ dari $5 / 11)$, dan

$\mathbf{P}($ Perngeluaran/Bulan $=$ banyak $\mid$ Pembelian $\mathrm{BBM}=$ sedang $)=0.454($ dari $5 / 11)$.

\subsection{Python Software}

Python pada dasarnya memiliki style yang serupa dengan pseudocode, perbedaannya hanyalah Python dapat dijalankan di komputer dan menampilkan hasil (Hall, 2005, p 10). Bahasa pemrograman Python mulai dikembangkan pada tanggal 20 Februari 1991 oleh Van Rossum. Python adalah sebuah bahasa pemrograman dinamis yang sering digunakan dalam pengembangan aplikasi pada berbagai domain. Bahasa Python mudah dimengerti (serupa dengan 
bahasa Inggris), dan tidak perlu proses kompilasi, maka dari itu kita dapat menjalankan script Python begitu kita menyimpannya tanpa memerlukan langkah lanjutan.

\subsection{Hardware Pengujian}

Perangkat keras yang digunakan penulis untuk implementasi aplikasi ini adalah sebagai berikut :

OS : Windows 10 Pro

Processor : : Intel ${ }^{\circledR}$ Core $^{\mathrm{TM}} \mathrm{i} 3-5005 \mathrm{U}$

CPU : : $92.00 \mathrm{GHz} 2.00 \mathrm{GHz}$

RAM : $4.00 \mathrm{~GB}$

System type : 64-bit Operating System, x64-based operation

Display Adapter : Intel(R) HD Graphics 5500 NVIDIA GeForce 930M

\subsection{Makalah Penulis Lain}

Untuk melengkapi penelitian, penulis juga membaca referensi-referens dari jurnal terkait seperti yang terlihat di bawah ini:

Tabel 1. Riset Penulis Lain

\begin{tabular}{|c|c|c|c|c|}
\hline No & Penulis & Tahun & Publikasi & Judul \\
\hline \multirow[t]{2}{*}{1} & $\begin{array}{l}\text { Karelena } \\
\text { Indriani, } \\
\text { Qonita } \\
\text { Tanjung }\end{array}$ & 2017 & $\begin{array}{l}\text { Publikasi Jurnal Penelitian Teknik } \\
\text { Informatika Universitas Prima Indonesia } \\
\text { (UNPRI) Medan Vol. 1, No. 2, Oktober } \\
2018 \text { e-ISSN: 2621-234x }\end{array}$ & $\begin{array}{l}\text { Sistem Pendukung Keputusan Kelayakan Kredit Motor } \\
\text { Menggunakan Metode Naive Bayes Pada NSC Finance } \\
\text { Cikampek }\end{array}$ \\
\hline & \multicolumn{4}{|c|}{$\begin{array}{l}\text { Kesimpulan: perusahaan mudah dan cepat untuk input data pendaftar, hasil analisa metode Naive Bayes dapat diperoleh dengan cepat, } \\
\text { tingkat akurasi sebesar } 99 \% \text { dan error } 1 \% \text { yang dibantu dengan aplikasi pendukung Rapidminer }\end{array}$} \\
\hline \multirow[t]{2}{*}{2} & $\begin{array}{l}\text { Harry Pribadi } \\
\text { Fitrian, Ikhwan } \\
\text { Ruslianto, } \\
\text { Rahmi } \\
\text { Hidayati }\end{array}$ & 2018 & $\begin{array}{l}\text { Jurnal Coding, Sistem Komputer Untan } \\
\text { Volume 06, No. } 02 \text { (2018), hal 13-24 ISSN: } \\
\text { 2338-493X }\end{array}$ & $\begin{array}{l}\text { ImplementasiMetode Naive Bayes Classifier Untuk } \\
\text { Aplikasi Filtering Email Spam Dengan Lemmatization } \\
\text { Berbasis Web }\end{array}$ \\
\hline & \multicolumn{4}{|c|}{$\begin{array}{l}\text { Kesimpulan: Waktu proses filtering file email dengan ukuran yang lebih kecil akan lebih cepat dari ukuran file email yang lebih besar. } \\
\text { Presentase keberhasilan filtering dari } 113 \text { file email adalah sebesar } 90,83 \%\end{array}$} \\
\hline 3 & $\begin{array}{l}\text { Mohamat Dodi } \\
\text { Trisetiyo, Jati } \\
\text { Sasongko } \\
\text { Wibowo }\end{array}$ & 2019 & $\begin{array}{l}\text { Prosiding SENDU_U } 2019 \text { ISBN: 978-979- } \\
\text { 3649-99-3 }\end{array}$ & $\begin{array}{l}\text { Klasifikasi Surat Menggunakan Metode Naive Bayes } \\
\text { Pada Sistem Informasi Manajemen Surat }\end{array}$ \\
\hline & \multicolumn{4}{|c|}{$\begin{array}{l}\text { Kesimpulan: pada uji pertama, nilai akurasi rendah } 33 \% \text { karena hasil konversi file .pdf tidak sesuai. Uji kedua menghasilkan akurasi } \\
88 \% \text {. Input data manual menhasilkan tingkat akurasi yang cukup tinggi. }\end{array}$} \\
\hline 4 & $\begin{array}{l}\text { Dina Lovita } \\
\text { Sari, Feri } \\
\text { Candra }\end{array}$ & 2019 & $\begin{array}{l}\text { Jom FTEKNIK Volume } 6 \text { Edisi } 1 \text { Janari s/d } \\
\text { Juni } 2019\end{array}$ & $\begin{array}{l}\text { Aplikasi Persediaan Barang Bangunan Cerdas } \\
\text { Menggunakan Metode Naive Bayes Berbasis Web }\end{array}$ \\
\hline & \multicolumn{4}{|c|}{$\begin{array}{l}\text { Kesimpulan: Aplikasi layak digunakan dengan tingkat akurasi 98,14\%. Aplkasi mampu mengelola data-data terkait, transaksi dan } \\
\text { pembuatan laporan. }\end{array}$} \\
\hline
\end{tabular}

\section{HASIL DAN ANALISIS}

Setelah dilakukan coding terhadap studi kasus ini, maka dilakukan pengujian terhadap apllikasi yang dibuat, yang terdiri dari beberapa tahapan:

\subsection{Data Training}

Langkah pertama yang dilakukan adalah proses baca data training. Pada kasus ini ada $\mathbf{1 0 0}$ data training/sampel. Adapun data training yang digunakan adalah data individu yang terdiri atas 50 pria dan 50 wanita, seperti berikut ini :

Tabel 2. Data Training

\begin{tabular}{|c|l|c|c|c|}
\hline No & \multicolumn{1}{|c|}{ Nama } & $\begin{array}{c}\text { Tinggi } \\
(\mathbf{c m})\end{array}$ & $\begin{array}{c}\text { Berat } \\
(\mathbf{K g})\end{array}$ & $\begin{array}{c}\text { Jenis } \\
\text { Kelamin }\end{array}$ \\
\hline 1 & $\begin{array}{l}\text { Randy } \\
\text { Carter }\end{array}$ & 184 & 73.0 & Pria \\
\hline 2 & $\begin{array}{l}\text { Stephanie } \\
\text { Smith }\end{array}$ & 149 & 52 & Wanita \\
\hline 3 & $\begin{array}{l}\text { Cynthia } \\
\text { Watson }\end{array}$ & 174 & 63 & Wanita \\
\hline
\end{tabular}

\begin{tabular}{|c|l|c|c|c|}
\hline No & \multicolumn{1}{|c|}{ Nama } & $\begin{array}{c}\text { Tinggi } \\
(\mathbf{c m})\end{array}$ & $\begin{array}{c}\text { Berat } \\
(\mathbf{K g})\end{array}$ & $\begin{array}{c}\text { Jenis } \\
\text { Kelamin }\end{array}$ \\
\hline 4 & $\begin{array}{l}\text { Jessie } \\
\text { Morgan }\end{array}$ & 175 & 67.0 & Pria \\
\hline 5 & $\begin{array}{l}\text { Katherine } \\
\text { Carter }\end{array}$ & 183 & 81 & Wanita \\
\hline 6 & David Reed & 187 & 60.0 & Pria \\
\hline 7 & $\begin{array}{l}\text { Stephen } \\
\text { Jones }\end{array}$ & 192 & 96.0 & Pria \\
\hline
\end{tabular}




\begin{tabular}{|c|c|c|c|c|}
\hline No & Nama & $\begin{array}{l}\text { Tinggi } \\
(\mathrm{cm})\end{array}$ & $\begin{array}{l}\text { Berat } \\
(\mathrm{Kg})\end{array}$ & $\begin{array}{c}\text { Jenis } \\
\text { Kelamin }\end{array}$ \\
\hline 8 & Jerry Allen & 204 & 91.0 & Pria \\
\hline 9 & Billy Wright & 180 & 66.0 & Pria \\
\hline 10 & Earl Green & 184 & 52.0 & Pria \\
\hline 11 & Todd Bell & 174 & 53.0 & Pria \\
\hline 12 & $\begin{array}{l}\text { Martin } \\
\text { White }\end{array}$ & 177 & 91.0 & Pria \\
\hline 13 & $\begin{array}{l}\text { Elizabeth } \\
\text { Ross }\end{array}$ & 138 & 37 & Wanita \\
\hline 14 & $\begin{array}{l}\text { Kenneth } \\
\text { Cox }\end{array}$ & 200 & 82.0 & Pria \\
\hline 15 & Frank Perry & 193 & 79.0 & Pria \\
\hline 16 & $\begin{array}{l}\text { Wayne } \\
\text { Sanders }\end{array}$ & 189 & 79.0 & Pria \\
\hline 17 & Carol King & 149 & 59 & Wanita \\
\hline 18 & Henry Smith & 188 & 53.0 & Pria \\
\hline 19 & Alan Foster & 187 & 81.0 & Pria \\
\hline 20 & $\begin{array}{l}\text { Paul } \\
\text { Henderson }\end{array}$ & 187 & 99.0 & Pria \\
\hline 21 & Jack Lewis & 190 & 81.0 & Pria \\
\hline 22 & $\begin{array}{l}\text { Christina } \\
\text { Foster }\end{array}$ & 161 & 48 & Wanita \\
\hline 23 & $\begin{array}{l}\text { Beverly } \\
\text { Long }\end{array}$ & 179 & 75 & Wanita \\
\hline 24 & $\begin{array}{l}\text { Bobby } \\
\text { Parker }\end{array}$ & 180 & 67.0 & Pria \\
\hline 25 & Keith Flores & 155 & 48.0 & Pria \\
\hline 26 & Carl Bryant & 201 & 122.0 & Pria \\
\hline 27 & $\begin{array}{l}\text { Sharon } \\
\text { Cooper }\end{array}$ & 162 & 62 & Wanita \\
\hline 28 & $\begin{array}{l}\text { Denise } \\
\text { Bryant }\end{array}$ & 148 & 49 & Wanita \\
\hline 29 & Brian King & 171 & 50.0 & Pria \\
\hline 30 & $\begin{array}{l}\text { Rebecca } \\
\text { Jenkins }\end{array}$ & 196 & 86 & Wanita \\
\hline 31 & $\begin{array}{l}\text { Alice } \\
\text { Sanders }\end{array}$ & 163 & 46 & Wanita \\
\hline 32 & $\begin{array}{l}\text { Ashley } \\
\text { Mitchell } \\
\end{array}$ & 159 & 57 & Wanita \\
\hline 33 & $\begin{array}{l}\text { Anthony } \\
\text { Anderson }\end{array}$ & 163 & 53.0 & Pria \\
\hline 34 & $\begin{array}{l}\text { Sarah } \\
\text { Edwards }\end{array}$ & 150 & 39 & Wanita \\
\hline 35 & $\begin{array}{l}\text { Betty } \\
\text { Griffin }\end{array}$ & 170 & 56 & Wanita \\
\hline 36 & Peter Harris & 191 & 55.0 & Pria \\
\hline 37 & Willie Lee & 175 & 67.0 & Pria \\
\hline 38 & $\begin{array}{l}\text { Kimberly } \\
\text { Martin }\end{array}$ & 169 & 78 & Wanita \\
\hline 39 & Julie Jones & 167 & 59 & Wanita \\
\hline 40 & $\begin{array}{l}\text { Albert } \\
\text { Lopez }\end{array}$ & 170 & 78.0 & Pria \\
\hline 41 & $\begin{array}{l}\text { Benjamin } \\
\text { Edwards }\end{array}$ & 178 & 79.0 & Pria \\
\hline 42 & $\begin{array}{l}\text { Donna } \\
\text { Howard } 168\end{array}$ & 168 & 71 & Wanita \\
\hline 43 & Marie Lewis & 170 & 37 & Wanita \\
\hline 44 & Paula Kelly & 167 & 58 & Wanita \\
\hline 45 & Irene Taylor & 152 & 43 & Wanita \\
\hline 46 & Steve Clark & 191 & 81.0 & Pria \\
\hline 47 & Barbara Hall & 155 & 48 & Wanita \\
\hline 48 & $\begin{array}{l}\text { Gerald } \\
\text { Turner }\end{array}$ & 176 & 61.0 & Pria \\
\hline
\end{tabular}

\begin{tabular}{|c|c|c|c|c|}
\hline No & Nama & $\begin{array}{l}\text { Tinggi } \\
(\mathrm{cm})\end{array}$ & $\begin{array}{l}\text { Berat } \\
(\mathrm{Kg})\end{array}$ & $\begin{array}{c}\text { Jenis } \\
\text { Kelamin }\end{array}$ \\
\hline 49 & $\begin{array}{l}\text { Evelyn } \\
\text { Peterson }\end{array}$ & 141 & 41 & Wanita \\
\hline 50 & Kelly Flores & 166 & 59 & Wanita \\
\hline 51 & $\begin{array}{l}\text { Craig } \\
\text { Collins }\end{array}$ & 168 & 46.0 & Pria \\
\hline 52 & Jessie Bell & 165 & 65 & Wanita \\
\hline 53 & $\begin{array}{l}\text { Douglas } \\
\text { Griffin }\end{array}$ & 169 & 67.0 & Pria \\
\hline 54 & $\begin{array}{l}\text { Laura } \\
\text { Rivera }\end{array}$ & 158 & 43 & Wanita \\
\hline 55 & $\begin{array}{l}\text { Joshua } \\
\text { Davis }\end{array}$ & 173 & 61.0 & Pria \\
\hline 56 & $\begin{array}{l}\text { Raymond } \\
\text { Kelly }\end{array}$ & 180 & 74.0 & Pria \\
\hline 57 & Eric Price & 212 & 59.0 & \\
\hline 58 & $\begin{array}{l}\text { Marilyn } \\
\text { Walker }\end{array}$ & 152 & 62 & Wanita \\
\hline 59 & $\begin{array}{l}\text { Shawn } \\
\text { Nelson }\end{array}$ & 189 & 67.0 & Pria \\
\hline 60 & $\begin{array}{l}\text { Jessie } \\
\text { Washington } \\
\end{array}$ & 159 & 56 & Wanita \\
\hline 61 & Diana Miller & 163 & 58 & Wanita \\
\hline 62 & Jessie Davis & 174 & 45 & Wanita \\
\hline 63 & $\begin{array}{l}\text { Justin } \\
\text { Richardson }\end{array}$ & 174 & 69.0 & Pria \\
\hline 64 & $\begin{array}{l}\text { Arthur } \\
\text { Rivera }\end{array}$ & 167 & 47.0 & Pria \\
\hline 65 & $\begin{array}{l}\text { Sandra } \\
\text { Johnson }\end{array}$ & 131 & 37 & Wanita \\
\hline 66 & Ann Perry & 154 & 74 & Wanita \\
\hline 67 & Helen Diaz & 159 & 59 & Wanita \\
\hline 68 & $\begin{array}{l}\text { Nicole } \\
\text { Bailey }\end{array}$ & 159 & 58 & Wanita \\
\hline 69 & Lisa Powell & 177 & 83 & Wanita \\
\hline 70 & Adam Ross & 193 & 96.0 & Pria \\
\hline 71 & Julia Brooks & 180 & 83 & Wanita \\
\hline 72 & Fred Taylor & 164 & 54.0 & Pria \\
\hline 73 & $\begin{array}{l}\text { Louise } \\
\text { Simmons }\end{array}$ & 164 & 64 & Wanita \\
\hline 74 & $\begin{array}{l}\text { George } \\
\text { Evans }\end{array}$ & 171 & 52.0 & Pria \\
\hline 75 & Anna Cox & 163 & 41 & Wanita \\
\hline 76 & $\begin{array}{l}\text { Jessie } \\
\text { Johnson }\end{array}$ & 165 & 30.0 & Pria \\
\hline 77 & $\begin{array}{l}\text { Brenda } \\
\text { Evans }\end{array}$ & 161 & 61 & Wanita \\
\hline 78 & $\begin{array}{l}\text { William } \\
\text { Powell }\end{array}$ & 198 & 75.0 & Pria \\
\hline 79 & $\begin{array}{l}\text { Deborah } \\
\text { Hughes }\end{array}$ & 183 & 70 & Wanita \\
\hline 80 & $\begin{array}{l}\text { Andrew } \\
\text { Roberts }\end{array}$ & 185 & 71.0 & Pria \\
\hline 81 & $\begin{array}{l}\text { Richard } \\
\text { Wilson } \\
\end{array}$ & 175 & 58.0 & Pria \\
\hline 82 & Harry Scott & 195 & 89.0 & Pria \\
\hline 83 & $\begin{array}{l}\text { Angela } \\
\text { Price }\end{array}$ & 170 & 66 & Wanita \\
\hline 84 & Sara Hill & 167 & 61 & Wanita \\
\hline 85 & $\begin{array}{l}\text { Maria } \\
\text { Jackson }\end{array}$ & 166 & 65 & Wanita \\
\hline 86 & Debra Gray & 180 & 88 & Wanita \\
\hline 87 & Chris Perez & 164 & 55.0 & \\
\hline
\end{tabular}




\begin{tabular}{|c|l|c|c|c|}
\hline No & \multicolumn{1}{|c|}{ Nama } & $\begin{array}{c}\text { Tinggi } \\
(\mathbf{c m})\end{array}$ & $\begin{array}{c}\text { Berat } \\
(\mathbf{K g})\end{array}$ & $\begin{array}{c}\text { Jenis } \\
\text { Kelamin }\end{array}$ \\
\hline 88 & $\begin{array}{l}\text { Lillian } \\
\text { Henderson }\end{array}$ & 161 & 53 & Wanita \\
\hline 89 & $\begin{array}{l}\text { Edward } \\
\text { Martin }\end{array}$ & 187 & 76.0 & Pria \\
\hline 90 & $\begin{array}{l}\text { Theresa } \\
\text { Collins }\end{array}$ & 170 & 63 & Wanita \\
\hline 91 & $\begin{array}{l}\text { Donald } \\
\text { Howard }\end{array}$ & 192 & 101.0 & Pria \\
\hline 92 & $\begin{array}{l}\text { Thomas } \\
\text { Ramirez }\end{array}$ & 175 & 56.0 & Pria \\
\hline 93 & $\begin{array}{l}\text { Johnny } \\
\text { Stewart }\end{array}$ & 190 & 100.0 & Pria \\
\hline 94 & $\begin{array}{l}\text { Matthew } \\
\text { Rodriguez }\end{array}$ & 164 & 63.0 & Pria \\
\hline
\end{tabular}

\begin{tabular}{|c|l|c|c|c|}
\hline No & \multicolumn{1}{|c|}{ Nama } & $\begin{array}{c}\text { Tinggi } \\
(\mathbf{c m})\end{array}$ & $\begin{array}{c}\text { Berat } \\
(\mathbf{K g})\end{array}$ & $\begin{array}{c}\text { Jenis } \\
\text { Kelamin }\end{array}$ \\
\hline 95 & $\begin{array}{l}\text { Phyllis } \\
\text { Clark }\end{array}$ & 172 & 61 & Wanita \\
\hline 96 & $\begin{array}{l}\text { Jessie } \\
\text { Thomas }\end{array}$ & 168 & 69 & Wanita \\
\hline 97 & $\begin{array}{l}\text { Emily } \\
\text { Gonzalez }\end{array}$ & 156 & 51 & Wanita \\
\hline 98 & $\begin{array}{l}\text { Doris } \\
\text { Nelson }\end{array}$ & 167 & 40 & Wanita \\
\hline 99 & $\begin{array}{l}\text { Louis } \\
\text { Bennett }\end{array}$ & 161 & 18.0 & Pria \\
\hline 100 & $\begin{array}{l}\text { Janice } \\
\text { Moore }\end{array}$ & 167 & 56 & Wanita \\
\hline
\end{tabular}

Hasil dari eksekusi terhadap data training adalah seperti berikut ini :

Wanita :

['Stephanie', 'Cynthia', 'Katherine', 'Elizabeth', 'Carol', 'Christina', 'Beverly', 'Sharon', 'Denise', 'Rebecca', 'Alice', 'Ashley', 'Sarah', Betty', 'Kimberly', 'Julie', 'Donna', 'Marie', 'Paula', 'Irene', 'Barbara', 'Evelyn', 'Kelly', 'Jessie', 'Laura', 'Marilyn', 'Jessie', 'Diana', 'Jessie', 'Sandra', 'Ann', 'Helen', 'Nicole', 'Lisa', 'Julia', 'Louise', 'Anna', 'Brenda', 'Deborah', 'Angela', 'Sara', 'Maria', 'Debra', 'Lillian', 'Theresa', 'Phyllis', 'Jessie', 'Emily', 'Doris', 'Janice']

[149174183138145161179162148196163159150170169167168170

167152155151166165158152159163174131154159159177180164

$163161183170167166180161170172168156167167]$

Pria :

['Randy', 'Jessie', 'David', 'Stephen', 'Jerry', 'Billy', 'Earl', 'Todd', 'Martin', 'Kenneth', 'Frank', 'Wayne', 'Henry', 'Alan', 'Paul', 'Jack', 'Bobby', 'Keith', 'Carl', 'Brian', 'Anthony', 'Peter', 'Willie', 'Albert', 'Benjamin', 'Steve', 'Gerald', 'Craig', 'Douglas', 'Joshua', 'Raymond', 'Eric', 'Shawn', 'Justin', 'Arthur', 'Adam', 'Fred', 'George', 'Jessie', 'William', 'Andrew', 'Richard', 'Harry', 'Chris', 'Edward', 'Donald', 'Thomas', 'Johnny', 'Matthew', 'Louis']

[184175187192204180184174177200193189188187187190180155

201171163191175170178191176168169173180212189174167193

$164171165198185175195164187192175190164161]$

\subsection{Feature Class}

Pada tahap pengujian ini, dibutuhkan label-label Tinggi dan Nama_awal. Label-label ini akan digabungkan dengan pengklasifikasian data tinggi badan pada interval $[130 . .134,135 . .139,140 . .144$, dan seterusnya]. Kemudian pengklasifikaisan tinggi pria dan tinggi wanita dengan metode Naïve Bayes. hasil eksekusi terhadap klasifikasi data tersebut dapat dilihat dibawah ini.

Pria $\{155: 1,160: 5,165: 4,170: 6,175: 7,180: 5,185: 8,190: 8,195: 2,200: 3\}$

Wanita $\{130: 1,135: 1,140: 0,145: 3,150: 5,155: 7,160: 8,165: 11,170: 7,175: 2,180: 4,185: 0\}$

Dengan memperhatikan data diatas, maka untuk pria yang memiliki tinggi tubuh $185 \mathrm{~cm}$ dan $190 \mathrm{~cm}$ akan muncul sebanyak 8 kali. Sedangkan untuk wanita adalah dengan yang bertubuh tinggi $165 \mathrm{~cm}$ dengan jumlah kemunculan sebanyak 11 kali. 


\subsection{Diagram Frekuensi Data}

Adapun hasil eksekusi penghitungan frekuensi/jumlah data ntuk maasing-masing nilai atribut dan kelasnya sebagai berikut dapat dilihat seperti bentuk garafik dibawah ini:

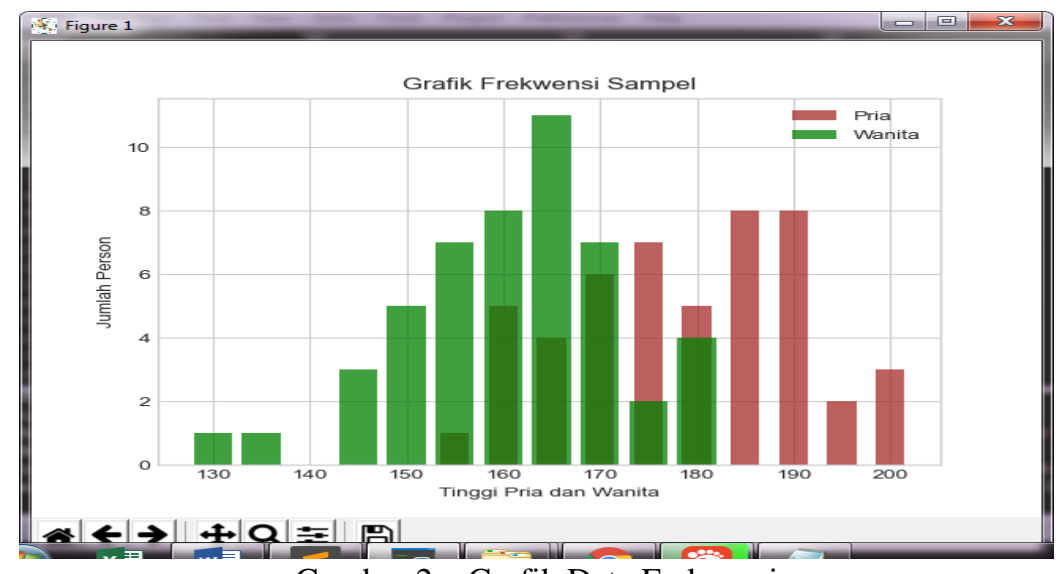

Gambar 2. Grafik Data Frekuensi

Pada gambar di atas, terlihat bahwa jumlah/frekuensi kemunculan data tinngi wanita lebih sering muncul dibandingkan data tinggi pria.

\subsection{Class Probabilitas}

Perhitungan Class Probabilities adalah jumlah/frekuensi data untuk setiap nilai kelas dibagi dengan total jumlah/frekuensi data training. Seperti halnya seperti pada Feature Class, hasil yang sama juga didapatkan pada kelas probalitias ini,

Pria $\{155: 1,160: 5,165: 4,170: 6,175: 7,180: 5,185: 8,190: 8,195: 2,200: 3\}$

Wanita $\{130: 1,135: 1,140: 0,145: 3,150: 5,155: 7,160: 8,165: 11,170: 7,175: 2,180: 4,185: 0\}$

\subsection{Pengujian terhadap kelas classifier}

Merupakan tahap akhir dari pengujian terhadap tinggi tubuh dari data pada tabel 2 mulai dari $130 \mathrm{~cm}$ hingga $215 \mathrm{~cm}$. Dan hasilnya adalah seperti berikut ini.

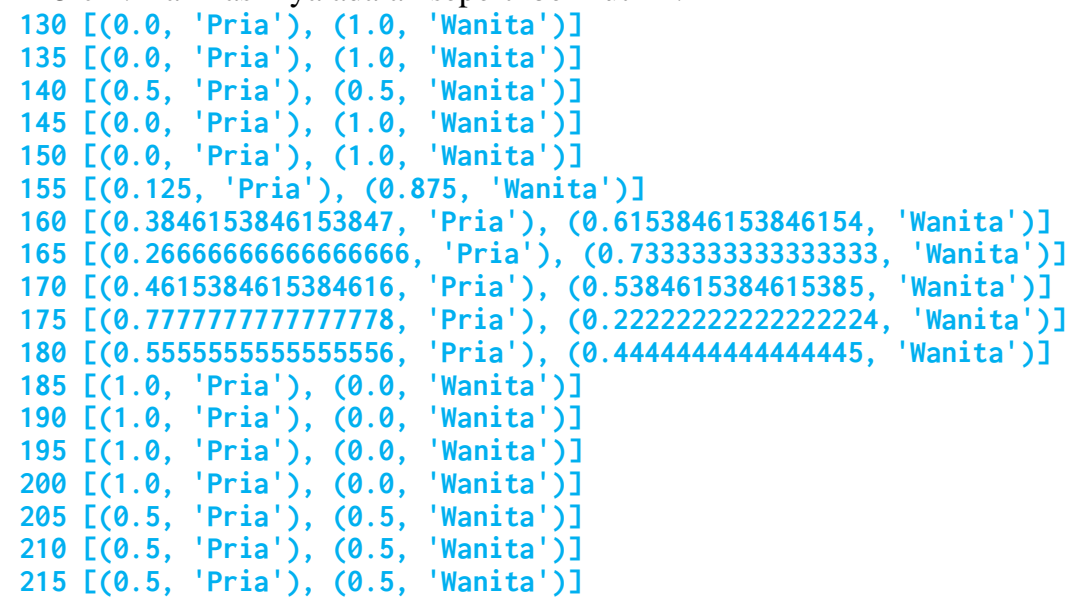


Adapun bentuk grafik dari data ouput di atas adalah seperti dibawah ini.

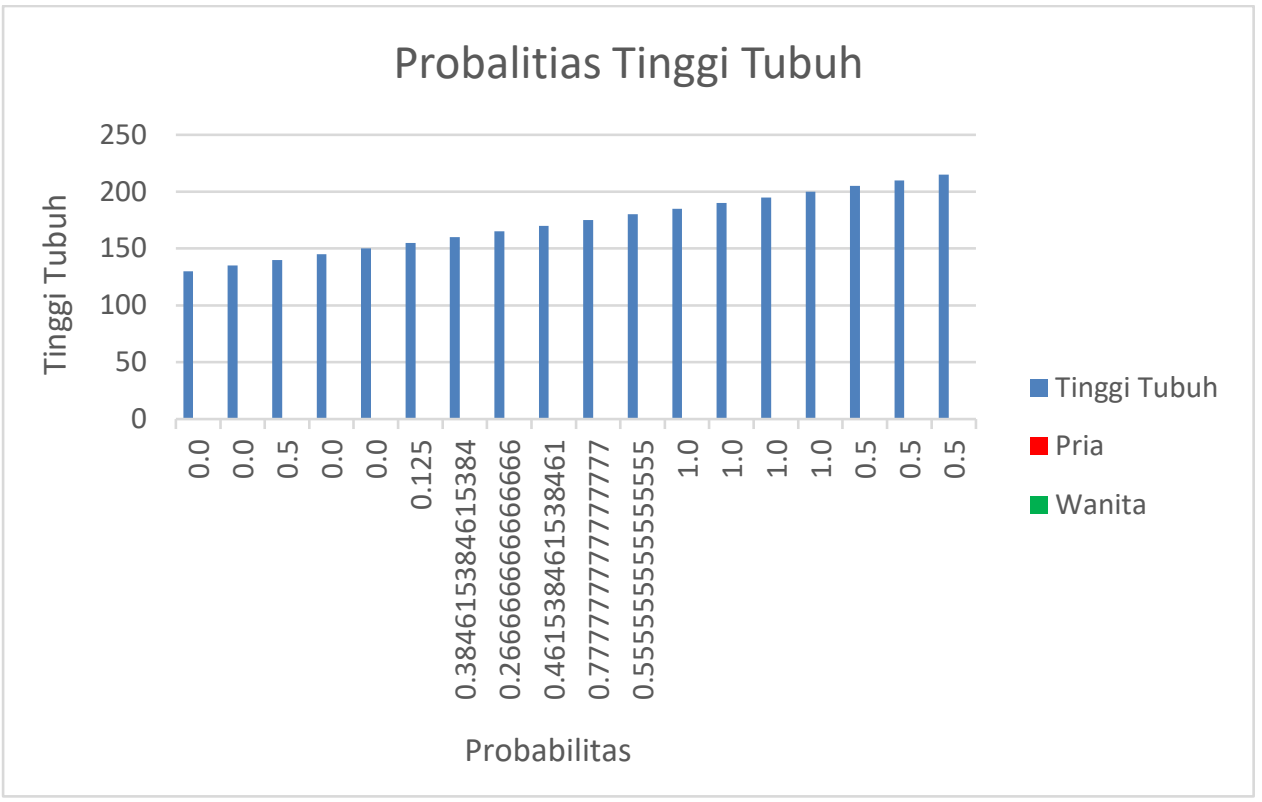

Gambar 3. Probabilitas tinggi tubuh

Gambar 3 menunjukkan bahwa tingkat probabilitas data tinggi tubuh wanita lebih besar daripada data tinggi tubuh pria. Jumlah total probabilitas tinggi tubuh pria mulai dari $130 \mathrm{~cm}$ hingga 215 adalah sebesar 8,6. Sedangkan probabilitas tinggi tubuh wanita $=9,6$.

\section{KESIMPULAN}

Dari tahap penelitian sampai pada tahap pengujian implementasi dengan data inputan, penulis membuat beberapa kesimpulan:

1. Rancang bangun aplikasi berbasis desktop dengan menggunakan bahasa pemrograman Python versi 3.7.2.

2. Nilai-nilai atribut dan probabilitas yang ada pada metode Naive Bayes Classifier dapat dioptimalkan melalui proses prediksi suatu kondisi berdasarkan inputan pada klarifikasi data terkait.

3. Dari hasil pengujian terhadap aplikasi didapatkan bahwa dengan menggunakan algoritma Nä̈ve Bayes Classifier, maka frekuensi kemunculan data klasifikasi tinggi tubuh wanita lebih banyak daripada data klasifikasi tinggi tubuh pria.

4. Jumlah probabilitas tinggi tubuh wanita lebih besar dari jumlah probabilitas tinggi tubuh pria.

\section{REFERENSI}

[1] I. D. and A. S. Suasmini, Penempatan Posisi Ketinggian Monitor Diturunkan Dapat Mengurangi Keluhan Subjektif Para Pemakai Kaca Bifokal, vol. 2, no. 11. Denpasar: Institut Seni Indonesia, 2011.

[2] Anonim, "Pentingnya Pengukuran Antropometri dalam Bidang Kesehatan di Indonesia," 2019. [Online]. Available: https://soloabadi.com/pentingnya-pengukuran-antropometri-dalam-bidang-kesehatan-diindonesia/. [Accessed: 21-Mar-2021].

[3] A. Irianton, Memantau dan Menilai Status Gizi Anak. Yogyakarta: Leutika Books, 2013.

[4] A. Istiany and Rusilanti, Gizi Terapan. Bandung: PT Remaja Rosdakarya, 2013.

[5] D. L. Olson and D. Delen, Advanced Data Mining Techniques. Verlag Berlin Heidelberg: Springer, 2008.

[6] D. Xhemali, C. J. Hinde, and R. G. Stone, "Naive Bayes vs. Decision Trees vs. Neural Networks in the Classification of Training Web Pages," Int. J. Comput. Sci., vol. 4, no. 1, pp. 16-23, 2009.

[7] Bustami, "Penerapan Algoritma Naive Bayes Untuk Mengklasifikasi Data Nasabah Asuransi," TECHSI J. Penelit. Tek. Inform., vol. 3, no. 2, p. 127, 2013.

[8] A. Saleh, "Implementasi Metode Klasifikasi Naive Bayes Dalam Memprediksi Besarnya Penggunaan Listrik Rumah Tangga," Citec J., vol. 2, no. 3, p. 207, 2015.

[9] I. Listiowarni, "Implementasi Naïve Bayessian dengan Laplacian Smoothing untuk Peminatan dan Lintas Minat Siswa SMAN 5 Pamekasan,” J. Sisfokom (Sistem Inf. dan Komputer), vol. 8, no. 2, p. 124, 2019. 